\title{
Description of Dental and Oral Health Maintenance Behavior of Elementary School Students
}

Gambaran Perilaku Pemeliharaan Kesehatan Gigi dan Mulut Siswa Sekolah Dasar

\author{
Laurencia A. N. Katili, Pritartha S. Anindita, Juliatri
}

Program Studi Pendidikan Dokter Gigi Fakultas Kedokteran Universitas Sam Ratulangi, Manado, Indonesia

Email: laurenciakatili@gmail.com

Received: January 14, 2022; Accepted: February 11, 2022; Published on line: February 13, 2022

\begin{abstract}
The 2018 Basic Health Research (Riskesdas) stated that the prevalence of students with dental and oral problems in North Sulawesi showed a fairly high number, which was $66.5 \%$. In children, behavioral factors that ignore dental and oral hygiene could affect the development of dental and oral health. Behavior can be measured by using three domains, namely knowledge, attitudes, and actions. This study aimed to obtain the description of dental and oral health maintenance behavior of elementary school students. This was a descriptive study with a cross sectional design. Population of this study were students at the elementary school SDN 1 Bulawan East Bolaang Mongondow, North Sulawesi, Indonesia. Meanwhile, samples were students of grades 5-6 totaling 44 children obtained by using total sampling method. Data were collected by using an online oral health maintenance behavior questionnaire via googleform. The results showed that the measurement scores were as follows: category of knowledge was 405; category of attitude was 394, category of action was 396, with a total score of 1195. In conclusion, the behavior of dental and oral health maintenance of students at SDN 1 Bulawan is classified as good.
\end{abstract}

Keywords: behavior; dental and oral health maintenance

\begin{abstract}
Abstrak: Riset Kesehatan Dasar (Riskesdas) 2018 menyebutkan bahwa prevalensi siswa yang bermasalah gigi dan mulut di Sulawesi Utara menunjukkan angka yang cukup tinggi yaitu sebesar $66,5 \%$. Pada anak faktor perilaku mengabaikan kebersihan gigi dan mulut berpengaruh terhadap perkembangan kesehatan gigi dan mulut. Perilaku dapat diukur dengan tiga domain yaitu pengetahuan, sikap, dan tindakan. Penelitian ini bertujuan untuk mendapatkan gambaran perilaku pemeliharaan kesehatan gigi dan mulut siswa sekolah dasar. Jenis penelitian ialah deskriptif dengan desain potong lintang. Populasi penelitian ini yaitu siswa di SDN 1 Bulawan, Bolaang Mongondow Timur, Sulawesi Utara. Sampel penelitian yaitu anak SDN kelas 5-6 berjumlah 44 orang. Teknik pengambilan sampel yang digunakan metode total sampling. Pengumpulan data menggunakan kuesioner perilaku pemeliharaan kesehatan gigi dan mulut secara online melalui googleform. Hasil penelitian mendapatkan bahwa skor hasil pengukuran kategori pengetahuan sebesar 405, kategori sikap 394, kategori tindakan 396, dengan skor total 1195. Simpulan penelitian ini ialah gambaran perilaku pemeliharaan kesehatan gigi dan mulut siswa SDN 1 Bulawan tergolong baik.
\end{abstract}

Kata kunci: perilaku; pemeliharaan kesehatan gigi dan mulut

\section{PENDAHULUAN}

Keadaan tubuh yang sehat merupakan keinginan setiap orang. Konsep sehat adalah keadaan yang bukan hanya sekedar terhin- dar dari penyakit melainkan suatu keadaan sehat secara fisik, mental maupun sosial. ${ }^{1}$ Kesehatan adalah keadaan sejahtera dari badan, jiwa dan sosial yang memungkinkan 
setiap orang hidup produktif secara sosial dan ekonomis. ${ }^{2}$ Salah satu faktor yang dapat memengaruhi kesehatan termasuk kesehatan gigi dan mulut yaitu faktor perilaku.

Perilaku seseorang merupakan suatu perbuatan atau tindakan terhadap organisme baik internal maupun eksternal yang dapat diamati dan dipelajari. Perilaku dapat diukur dengan tiga domain yaitu pengetahuan, sikap, dan tindakan. ${ }^{3}$

Perilaku kesehatan adalah suatu respons yang berkaitan dengan sakit dan penyakit. ${ }^{4}$ Perilaku dalam pemeliharaan kesehatan gigi dan mulut yang baik berperan penting untuk menentukan derajat kesehatan gigi dan mulut. Orang tua dan guru memegang andil yang sangat besar bagi kesehatan gigi dan mulut anak sejak usia dini. ${ }^{5}$ Batas usia anak yaitu sejak anak di dalam kandungan sampai usia 19 tahun. $^{6}$

Riset Kesehatan Dasar (Riskesdas) 2018 menyebutkan bahwa prevalensi siswa yang bermasalah gigi dan mulut di Sulawesi Utara menunjukkan angka yang cukup tinggi yaitu sebesar $66,5 \% .^{7}$ Data tersebut menyatakan bahwa kesehatan gigi dan mulut merupakan salah satu kesehatan jasmani yang perlu diperhatikan. Tingginya angka masalah gigi dan mulut terjadi akibat perilaku kesehatan gigi dan mulut yang buruk. ${ }^{3,4}$

Penyebab meningkatnya masalah kesehatan gigi dan mulut yaitu masih banyak siswa yang menyikat gigi dengan waktu yang tidak tepat, makan makanan manis (kariogenik), serta tidak melakukan pemeriksaan rutin ke dokter gigi. Untuk meningkatkan kesehatan gigi dan mulut diperlukan pemeliharaan yang baik dan tepat dalam kehidupan sehari-hari. Upaya pemeliharaan kesehatan gigi dan mulut perlu mendapatkan perhatian khusus terutama pada anak usia sekolah karena pada masa ini anak menjalani proses tumbuh kembang. Pada anak faktor perilaku mengabaikan kebersihan gigi dan mulut berpengaruh terhadap perkembangan kesehatan gigi dan mulut. ${ }^{3,4}$

Penelitian sebelumnya yang dilakukan oleh Rompis et $\mathrm{al}^{5}$ di SD Katolik Desa Wori Kecamatan Wori Kabupaten Minahasa
Utara, menyatakan bahwa perilaku pemeliharaan kesehatan gigi dan mulut pada anak sekolah tergolong baik. Penelitian serupa dilakukan oleh Sihombing et $\mathrm{al}^{8}$ di SDN 101896 Desa Kiri Hulu Kecamatan Tanjung Morawa Propinsi Sumatera Utara, menunjukkan bahwa gambaran pengetahuan, sikap dan tindakan pemeliharaan kesehatan gigi dan mulut pada anak rata-rata tergolong baik.

Sekolah Dasar Negeri 1 (SDN 1) Bulawan terletak di Kecamatan Kotabunan, Kabupaten Bolaang Mongondow Timur. Hasil survei awal yang dilakukan penulis mendapatkan bahwa sekolah tersebut pada saat ini melakukan pembelajaran secara dalam jaringan (daring) yang membuat pengetahuan tentang kesehatan gigi dan mulut yang biasa dilakukan di sekolah oleh Usaha Kesehatan Gigi Sekolah (UKGS) terhenti, demikian pula penanganan sikap mengabaikan menyikat gigi di waktu yang tepat serta tindakan pemeriksaan secara rutin ke dokter gigi juga terhenti, yang mengakibatkan masalah kesehatan gigi dan mulut semakin meningkat. Hal ini mendorong penulis untuk melakukan penelitian mengenai gambaran perilaku pemeliharaan kesehatan gigi dan mulut siswa SDN 1 Bulawan.

\section{METODE PENELITIAN}

Penelitian ini dilakukan terhadap siswa SDN 1 Bulawan di Kecamatan Kotabunan, Kabupaten Bolaang Mongondow Timur. Jenis penelitian ialah deskriptif dengan desain potong lintang dan dilakukan pada bulan Juli 2021. Sampel yang digunakan yaitu siswa kelas 5-6 berjumlah 44 anak, diperoleh dengan teknik pengambilan sampel secara total sampling.

Pengukuran perilaku pemeliharaan kesehatan gigi dan mulut menggunakan kuesioner sebanyak 15 pertanyaan yang telah dilakukan uji validitas dengan nilai $r$ hitung lebih dari $\mathrm{r}$ tabel maka dikatakan valid dan uji reliabilitas dengan nilai $\alpha$ lebih dari 0,60. Pertanyaan terdiri dari masingmasing lima pertanyaan tentang pengetahuan, sikap, dan tindakan. Hasil pengukuran 
kuesioner menggunakan skala Guttman. Jawaban masing-masing pertanyaan dibagi menjadi dua kategori, yakni jawaban ya atau tidak. Jawaban ya diberi skor 2 dan jawaban tidak diberi skor 1 . Skor 15 pertanyaan pengetahuan, sikap dan tindakan untuk jumlah responden seluruhnya ialah:

skor tertinggi $=2 \times 15 \times 44=1320$ dan

skor terendah $=1 \times 15 \times 44=660$

Hasil perhitungan tersebut kemudian dikategorikan menjadi dua kategori yaitu baik dan buruk. Nilai skor 660-989 tergolong kategori buruk sedangkan nilai skor 990-1320 tergolong kategori baik. Pengumpulan data menggunakan kuesioner perilaku pemeliharaan kesehatan gigi dan mulut secara online melalui googleform

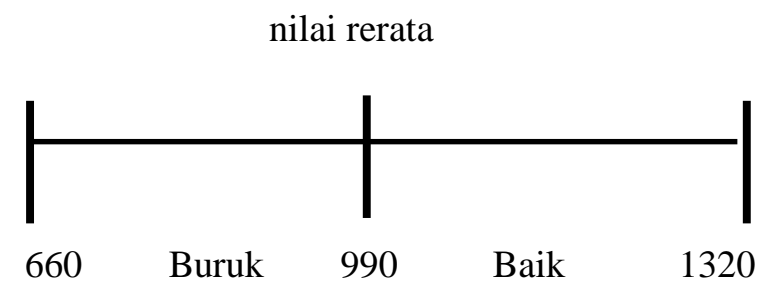

Data yang diperoleh pada penelitian dianalisis untuk mengetahui frekuensi dan distribusi dari karakteristik responden lalu disajikan dalam bentuk tabel.

\section{HASIL PENELITIAN}

Sekolah Dasar Negeri 1 Bulawan berlokasi di Desa Bulawan Kecamatan Kotabunan Kabupaten Bolaang Mongon-dow Timur. Sekolah ini memiliki jumlah siswa sebanyak 294 siswa dan 12 guru pegawai negeri sipil (PNS).

Responden penelitian berjumlah 44 siswa dan dikategorikan berdasarkan jenis kelamin, kelas, dan usia. Tabel 1 memperlihatkan bahwa responden perempuan lebih banyak dibandingkan laki-laki. Jumlah responden kelas lima dan enam SDN 1 Bulawan sama banyak yaitu 22 siswa. Responden terbanyak berusia 11 tahun dan yang paling sedikit berusia 9 dan 13 tahun.

Tabel 2 memperlihatkan distribusi perilaku responden berdasarkan pengetahuan, sikap, dan tindakan. Persentase tertinggi didapatkan pada pengetahuan baik $(91 \%)$; sikap baik (95\%); dan tindakan baik (98\%).
Tabel 1. Distribusi frekuensi responden $(n=44)$ berdasarkan jenis kelamin, kelas, dan usia

\begin{tabular}{lcc}
\hline Kategori & n & \% \\
\hline Jenis kelamin & & \\
$\quad$ Perempuan & 23 & 52,3 \\
$\quad$ Laki-laki & 21 & 47,7 \\
Kelas & & \\
5 & 22 & 50,0 \\
6 & 22 & 50,0 \\
Usia (tahun) & & \\
9 & 1 & 2,3 \\
10 & 12 & 27,3 \\
11 & 18 & 40,8 \\
12 & 12 & 27,3 \\
13 & 1 & 2,3 \\
\hline
\end{tabular}

Tabel 2. Distribusi perilaku responden $(n=44)$ berdasarkan pengetahuan, sikap, dan tindakan

\begin{tabular}{ccc}
\hline Kategori & Jumlah & Persentase \\
\hline Pengetahuan & & \\
Baik & 40 & 91 \\
Buruk & 4 & 9 \\
Sikap & & \\
Baik & 42 & 95 \\
Buruk & 2 & 5 \\
Tindakan & & \\
Baik & 43 & 98 \\
Buruk & 1 & 2 \\
\hline
\end{tabular}

Tabel 3 memperlihatkan bahwa skor hasil pengukuran perilaku pada 44 responden mendapatkan skor hasil pengukuran pengetahuan lebih tinggi dibandingkan skor hasil pengukuran sikap dan tindakan, dengan skor total 1195. Berdasarkan hasil penelitian tersebut didapatkan bahwa perilaku responden siswa SD Negeri 1 Bulawan terhadap pemeliharaan kesehatan gigi mulut sudah tergolong baik.

Tabel 3. Distribusi frekuensi skor hasil pengukuran perilaku

\begin{tabular}{cc}
\hline Kategori & $\begin{array}{c}\text { Skor Hasil } \\
\text { Pengukuran }\end{array}$ \\
\hline Pengetahuan & 405 \\
Sikap & 394 \\
Tindakan & 396 \\
Total & 1195 \\
\hline
\end{tabular}


Skala hasil pengukuran perilaku berdasarkan perolehan skor sebagai berikut:

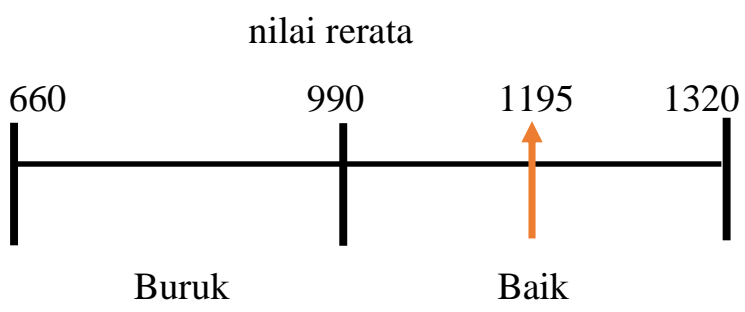

\section{BAHASAN}

Berdasarkan hasil pengukuran tingkatan pengetahuan responden (Tabel 2) tentang pemeliharaan kesehatan gigi mulut sudah tergolong baik dengan jumlah reponden masuk dalam kategori baik sebanyak 40 anak dan yang buruk sebanyak empat anak. Hal ini dikarenakan informasi mengenai kesehatan gigi dan mulut telah banyak dipublikasi melalui media cetak dan media elektronik. Di era sekarang ini informasi sangat mudah untuk diakses oleh masyarakat termasuk anak sekolah dasar yang sudah tidak asing dengan penggunaan media internet. Teknologi internet bagi anak sekolah dasar sangat penting untuk mencari tahu pengetahuan yang mendukung. ${ }^{9}$ Selain itu berbagai iklan masyarakat di media cetak, media elektronik (televisi, radio, internet) dan media promosi lainya berperan dalam menyebarkan berbagai informasi berkaitan dengan pemeliharaan kesehatan gigi dan mulut yang turut membentuk pengetahuan responden yaitu siswa sekolah dasar. Pengetahuan merupakan ranah yang sangat penting bagi terbentuknya perilaku seseorang.

Hasil pengukuran sikap responden (Tabel 2) terhadap pemeliharaan kesehatan gigi dan mulut sudah tergolong baik dengan jumlah reponden masuk dalam kategori baik sebanyak 42 reponden dan yang buruk sebanyak dua responden. Menurut penulis hal ini terjadi karena sebelumnya sudah ada stimulus yang berkaitan dengan informasi atau pengetahuan tentang pemeliharaan kesehatan gigi mulut yang terlihat dari tingkat pengetahuan responden yang sudah tergolong baik. Sikap yang baik akan berpe- ngaruh terhadap perilaku nyata responden. Hasil ini didukung dengan penelitian yang dilakukan oleh Sukamto ${ }^{10}$ terhadap anak kelas 5 dan 6 Sekolah Dasar yang menyatakan bahwa kurangnya pengetahuan, sikap, serta tindakan akan memengaruhi kesehatan gigi dan mulut anak Sekolah Dasar Kelurahan Mowa Kota Palopo.

Hasil pengukuran tindakan responden (Tabel 2) terhadap kesehatan gigi dan mulut, memperlihatkan bahwa hasilnya juga tergolong baik dengan jumlah reponden masuk dalam kategori baik sebanyak 43 reponden dan yang buruk hanya satu responden. Tindakan merupakan suatu perilaku yang dilaksanakan seseorang setelah mengetahui dan menyikapi suatu respon. ${ }^{9}$ Tindakan dapat diartikan dengan sikap nyata, tetapi sikap belum tentu akan terwujud menjadi sebuah tindakan. Beberapa aspek yang berpengaruh terhadap tindakan meliputi, aspek pengetahuan, perilaku sehat orang lain sebagai panutannya, dan sumber daya. Semakin baik pengetahuan maka akan semakin baik juga tindakannya. ${ }^{11}$

Dari data hasil pengukuran perilaku (Tabel 3) terlihat gambaran bahwa secara keseluruhan perilaku pemeliharaan kesehatan gigi dan mulut siswa SD Negeri 1 Bulawan sudah tergolong baik dengan hasil skoring 1195. Hasil ini sejalan dengan penelitian Rompis et $\mathrm{al}^{5}$ di SD Katolik Desa Wori Kecamatan Wori Kabupaten Minahasa Utara, menyatakan bahwa perilaku pemeliharaan kesehatan gigi dan mulut pada anak sekolah tergolong baik. Perilaku siswa tergambar dari tingkat pengetahuan, sikap serta tindakannya. Suatu tindakan atau praktik merupakan bentuk perilaku yang terbuka. Terbuka dalam artian perilaku sudah bisa dilihat atau tampak bagi orang lain. Perilaku antara lain dipengaruhi oleh sikap. Sikap yang baik akan mendukung terbentuknya perilaku nyata yang baik. ${ }^{9}$

Dari hasil keseluruhan terlihat bahwa kuesioner perilaku yang digunakan belum sepenuhnya bisa menggali informasi tentang perilaku responden sebagaimana diharapkan. Penulis mengakui keterbatasan penelitian ini dengan harapan ke depan akan 
dilakukan penelitian sejenis dengan kuesioner lebih spesifik sehingga benar-benar mampu mengukur perilaku pemeliharaan kesehatan gigi mulut individu secara akurat.

\section{SIMPULAN}

Gambaran perilaku pemeliharaan kesehatan gigi dan mulut siswa SDN 1 Bulawan, Bolaang Mongondow, Sulawesi Utara, sudah tergolong baik.

\section{Konflik Kepentingan}

Penulis menyatakan tidak terdapat konflik kepentingan dalam studi ini.

\section{DAFTAR PUSTAKA}

1. Leonardi F. The Definition of Health: Towards New Perspectives. Int J Heal Serv. 2018; 48(4):735-48.

2. Undang-Undang Republik Indonesia Nomor 23 Tahun 1992 Tentang Kesehatan [Internet]. Vol. 3, Menteri/Sekretaris Negara Republik Indonesia. 1992 [cited 2021 Mar 8]. p. 1-53. Available from: https:// peraturan.bpk.go.id/Home/Details/ 46620/uu-no-23-tahun-1992

3. Ahmad K. Promosi Kesehatan dengan Pendekatan Teori Perilaku, Media dan Aplikasinya. Depok: Rajawali Pers; 2018. p 17-8.

4. Marjes TN. Promosi Kesehatan (1st ed). Sidoarjo: Indomedia Pustaka; 2018. p. 164.

5. Rompis KR, Wowor VNS, Mintjelungan CN.
Gambaran perilaku pemeliharaan kesehatan gigi mulut dan indeks plak siswa SD Katolik Wori. eBiomedik. 2019; 7(2):98-101.

6. Soediono B. Info Datin Kemenkes RI Kondisi Pencapaian Program Kesehatan Anak Indonesia. J Chem Inf Model. 2014; 53:160.

7. Badan penelitian dan pengembangan kesehatan kementerian kesehatan RI. Riset Kesehatan Dasar (RISKESDAS). 2018. p. 182-95

8. Sihombing KP, Simare-mare RT, Tobing AN. Description of knowledge, attitudes, and actions about dental and oral health maintenances of students in primary school of 101896 of Kiri Hulu-I Tanjung Morawa Disctrict of Sumatera Utara Province. J Kesehat Gigi. 2020;8(1):11723.

9. Hanifah SU, Irna SL, Haibati LK, Puji LA, Ayuning A. Peran teknologi dalam pembelajaran di masa pandemi Covid19. Al-Mutharahah J Penelit dan Kaji Sos Keagamaan. 2020;17(2):188-98.

10. Sukamto S. Hubungan perilaku pemeliharaan kesehatan gigi dan mulut terhadap karies pada anak. JIKI J Ilm Kesehat IQRA [Internet]. 2021;9:17-21. Available from: https://stikesmu-sidrap.ejournal.id/JIKI/ article/view/243

11. Namira HM. Hubungan pengetahuan, sikap dan tindakan kesehatan gigi dan mulut terhadap tingkat kerusakan gigi pada siswa SMP. Dentin. 2021;V(1):47-51. 